\title{
From revelation to revolution: apocalypticism in green politics
}

Wallace McNeish

This is the accepted manuscript of an article published by Taylor \& Francis in Environmental Politics on 25th June 2017 available online: http://dx.doi.org/10.1080/09644016.2017.1343766 


\title{
From Revelation to Revolution: Apocalypticism in Green Politics
}

\author{
Wallace McNeish \\ Division of Sociology, Abertay University, Dundee, Scotland \\ E-mail: w.mcneish@abertay.ac.uk
}

\begin{abstract}
Apocalyptic narratives in green politics have provoked much controversy about questions of rhetoric and framing. Critics argue that constant warnings about impending environmental collapse demoralise and demobilise the public, while advocates argue that dire predictions embody a realism necessary if the radical collective action required for a green transition is to be taken. This is not just a debate about the tactics of presentation; at a substantive ideological level, the multi-layered questions raised by apocalypticism cut to the heart of significant divisions in the green movement between radical and mainstream currents concerning their orientation to structures of political and economic power. Comparisons with the contested historical tradition of apocalyptics in Christian theology shed light upon the dynamic tensions between movement insurgency and institutionalisation. Apocalypticism has played a key role in framing the green critique of capitalist modernity, and is intrinsically connected to the formulation of utopic alternatives. In both theory and practice it remains the animating spirit of radical environmentalism.
\end{abstract}

Keywords: apocalypse, utopia, green ideologies, social movements, Christian theology. 


\section{Introduction}

'We live in a time in which the confrontation of reality with reason requires us to ask apocalyptic questions... What makes the raising of these questions rational and necessary, today, is that scientific research is consistently telling us that if current trends continue, even for a century, the results for the earth and its inhabitants will be a collapse of the world as we know it' (Foster 2009, p. 11)

'The day of the Lord shall come as a thief in the night; in which the heavens shall pass away with a great noise, and the elements shall melt with fervent heat, the earth also and the works that are therein shall be burned up' ( $2^{\text {nd }}$ Peter, Chapter 3 , Verse 10 )

Like the historical tradition of Christian eschatology that has long preached 'the end is nigh', but with burgeoning scientific evidence to support its claim, contemporary environmentalism warns of impending planetary apocalypse. As in Pascal's wager on the existence of a judgemental God (Pascal 1995 [1670]), it asks 21 ${ }^{\text {st }}$ century governments and societies to engage in a rational calculus of finite probability against infinite consequences. Climate science points to the strong probability that unchecked anthropogenic global warming and related environmental degradation will lead to the collapse of the eco-systems that sustain the rich diversity of human and non-human life on earth (IPCC 2014), and will have catastrophic effects upon market economic systems and inter-state relations (Stern 2007, Nordhaus 2013). Global change towards a low carbon economy is urgently required, which involves a fundamental reorientation of the nature-society relationship. Such change is likely to prove costly in terms of consumer lifestyle and disruption of normalised carbon intensive practices across all socioeconomic spheres. Even if the science ultimately proves to be misguided, the precautionary action entailed by the green wager is worth taking, because like Pascal's wager on eternity for the soul, all that will have been lost are a few transient 'earthly pleasures' set against the benefits of an infinite future of planetary and species survival.

Following Hall's (2009b, p. 1.2) definition, 'the apocalyptic encompasses a broad range of beliefs, actions, and social processes centred on cultural disjunctures concerned with 'the end of the world' and thereafter'. The etymology of the word 'apocalypse' has roots in the Greek apokalyptein (apo - 'from' and kalyptein - 'to cover or conceal'), which translates as 'an uncovering', 'disclosure' or 'revelation'. 'Apocalypse' in this original usage signifies a radical change in consciousness, which potentially facilitates action to transform the self and social 
relations. In Christian eschatology -- the branch of theology that deals with the fate of humanity -- God's apocalyptic design is discerned through study of biblical texts, prophecy and the interpretation of historical events. Revelation, written by John of Patmos, is the most significant source for Christian apocalyptics. It contains a mish-mash of cryptic allegorical visions about God's wrathful final judgement, and the return of Jesus Christ in power and glory to establish a thousand-year rule of peace and harmony for a cleansed humanity - the millennium - before a final victorious battle with Satan and the forces of evil at the end of time. Christianity, and especially the most lurid passages in the book of Revelation, has profoundly shaped the western cultural imagination, where the apocalypse has come to connote a future cataclysmic reckoning for humanity, the collapse of civilisation and perhaps even annihilation of all life (Weber 1999). However, as Hall (2009b, p. 1.2) indicates in his analysis of the relationship between apocalypticism and the 'empire of modernity', the meaning of 'apocalypse can be shifted out of its typically religious register by noting that apocalyptic texts usually are not about the End, but about the Present Crisis'.

Climate change has come to operate as what social movement theorists call a master frame (Snow and Benford 1992), for the green movement's analysis of the Present Ecological Crisis. Hence traditional environmental issues - species extinction, resource depletion, population, pollution and habitat destruction - tend to be understood and presented through its lens. This may be inevitable given the significance of the climate issue, but it also means that apocalyptic narratives, ever present in radical green critique (Dobson 1995, Buell 2004), have become increasingly pronounced and culturally diffused as the scientific revelation of serious negative ecological and social impacts continues to mount. Urry (2011, p. 38), for example, lists a far from exhaustive catalogue of 25 recently published popular books which express 'the new catastrophism' in social and scientific thought pertaining to global warming. If eco-dystopic fiction - so called 'cli-fi' - is added (e.g. the work of major writers as diverse as Cormac McCarthy, Kim Stanley Robinson and Margaret Atwood, alongside films such as Waterworld 1995, The Day After Tomorrow 2004, Mad Max: Fury Road 2015), and documentaries such as Chasing Ice 2011, An Inconvenient Truth 2006, The Age of Stupid 2009), it becomes clear that apocalyptic discourse is a major mediating frame through which publics have come to engage with the issue of climate change, and by proxy with wider green politics.

Apocalyptic narratives in green politics have however proven to be deeply divisive (Foust and Murphy 2009). On the one hand, critics such as Giddens (2015), who argue that fear-driven 
discourses which moralise about potential risks and dangers of climate change to induce greenethical behaviour in a consumption driven society are self-defeating. Apocalypticism is viewed as counterproductive because it enables opponents to label the environmental movement alarmist (Leiserowitz 2005) or hysterical (Hoggert 2011), while encouraging media sensationalism and fatalistic attitudes amongst publics which detract from political agency (McKinley 2008, Swyngedouw 2010, Feinberg and Willer 2011), even leading ultimately to the so called 'death of environmentalism' (Shellenberger and Nordhaus 2004). On the other hand, are commentators who argue that apocalyptic discourses play a vital role in creating the sense of urgency that is an essential spur to activism (Taylor 1991, Thompson 2009), while importantly challenging modernity's animating narrative myth of unbounded liberal progress (Ginn 2015). Indeed, Veldman (2012, p. 2 and 3) notes, that apocalypticism creates a valuable interpretive framework for environmentally ethical behaviour, and that 'a fair amount of environmental activism occurs not despite apocalypticism but because of it'. For Angus (2013), the pleas made for an alternative positive narrative concerning global warming made by critics of 'catastrophism' are disingenuous because those same critics know the apocalyptic nature of the conclusions being drawn by climate science. Hence, in developing solutions to the global warming threat 'the first step is to tell the truth - about the danger we face' (Angus 2013, p. 28).

I aim here to get behind the headline arguments of this binary debate. On the surface, it might appear to revolve primarily around tactical questions of presentation, rhetoric and framing. I contend that, at a deeper ideological level, the multi-layered questions raised by apocalypticism cut to the heart of significant divisions in the contemporary green movement between radical and mainstream currents concerning their orientation to political and economic power structures. As Hall et al (2000, p. 8), argue, 'to understand the apocalyptic, we need to look to the (potentially contested) utopian and ideological narratives that come to frame it'. To this end, I begin by contextualising the apocalypse as an important form of recurrent narrative myth that has impacted deeply upon the theological history of Christianity and has a complex, often fraught relationship, to ideology, utopia, and modernity. I then proceed to examine the different ways in which apocalypticism has been deployed in the history and ideology of modern environmentalism. Comparisons with the contested tradition of apocalyptics in the history of Christian theology are made that shed new light upon tensions between movement insurgency and institutionalization. 
Analysis will show that because apocalypticism has played such a pivotal historical role in framing the green critique of capitalist modernity, and is intrinsically connected to the formulation of utopic alternative futures, it cannot simply be side-lined as a kind of embarrassing anachronism. Indeed to do so, would be to jettison the critical animating spirit of modern green politics, leading to the real death of environmentalism as a force for radical social and economic change. Instead, I will argue that the original meaning of apocalypse as revelation needs to be reclaimed and fused with radical green critiques of the Present Ecological Crisis which offer inspirational utopian narratives, if the popular meaning of apocalypse as the end of human civilisation is to be avoided both in figurative and literal terms.

\section{Historical Apocalypticism}

The mythic narrative of the apocalypse originated after 1500BC with Zoroaster (Zarathustra), the first millenarian prophet, whose teachings formed the basis of the world's first eschatological faith (Cohn 1995). Zoroaster broke with synchronic conceptions of temporality which viewed the order of the world as unchanging, and the pattern of events and experience as eternally recurrent. He suggested that history and time were bound up in motion towards a consummation whereby 'the present, imperfect world will be replaced by a new, perfect and unthreatened world' (Cohn 1995, p. 21). Here at its inception, the apocalypse is indelibly linked to utopia and millenarian hope; indeed, the 'great transformation' is referred to in Zoroastrian prophetic scripture as 'the making wonderful', when the final battle between good and evil is won (Cohn 1995, p, 29). Humans must actively choose sides in this dualistic drama, and live in preparation for the final reckoning and the post-apocalyptic transition. Zoroaster's teleological worldview instigated an apocalyptic imagination concerning the fate of humanity which gradually permeated through Graeco-Roman philosophy and culture, and influenced the development of the monotheistic world religions, Judaism, Christianity and Islam.

According to McIntosh (2010, p. x), the Christian New Testament apocalypse as disclosed in the book of Revelation implied 'an astonishing irruption of new hope' in history. It set out an emancipatory 'transformative meekness' which inspired the early Christians living under the persecution of the Roman Empire, and led to its eventual overthrow. Radical millenarian beliefs 
sustained the marginalised Church of the slaves and the oppressed, with the promise of an imminent apocalyptic destruction of Roman tyranny, divine retribution and the creation of a new, just and harmonious society (the millennium), presided over by Jesus and the saints. Variations on such beliefs have historically been the lifeblood of millenarian or chiliastic social movements which can be loosely defined as expecting 'immediate, collective, total, thisworldly salvation'. Such movements usually arise in periods of socio-political uncertainty and 'anticipate the complete destruction of the existing social, political and economic order, which will be superseded by a new and perfect society' (Barkun 1986, p. 18).

With the legal establishment of the Christian Church and its fusion with the Roman state in the $4^{\text {th }}$ century, Christian theologians pragmatically reinterpreted the biblical apocalypse. Amillennialism, as championed by Augustine and Jerome, became Roman Catholic orthodoxy. In this theology, the apocalypse and the subsequent thousand-year reign of Christ and the saints predicted in Revelation is interpreted figuratively. For amillennialists, Christ will return at some indiscernible point in the future to establish his perfect kingdom, but in the meantime Christians should respect the temporal authority of the Church which is symbolic of the already established millennium that exists in the hearts of believers (Wojcik 1997, p. 34). With the official adoption of Augustinian theology, literal interpretations of an imminent apocalypse, and attempts to predict Christ's return, which had been prevalent during the initial Christian insurgency, were outlawed as heresies (Cochrane 2003, McGinn 1995). Amillenialism is the mode by which church institutions tempered the disruptive zeal amongst believers generated by the apocalyptic narrative and put it to use in the service of institutional power interests. Instead of a movement, Christianity became a bureaucratized institution with a defined hierarchy and rigid theology which enabled survival during the traumas of the centuries following the collapse of the Roman Empire. At the same time, however, it arguably lost its critical animating spirit, which emphasised a social gospel of engagement with the poor and empowerment of the marginalised.

Two key competing traditions of apocalypticism developed historically to challenge the dominance of amillennialism in Christian eschatology: post-millennialism and premillennialism. Post-millennialism posits that it is Christian duty to build a just and godly community, the millennial rule of the saints on Earth, in anticipation of Christ's immanent apocalyptic return in power and glory (Northcott 2004). This eschatology was particularly influential amongst utopian post-Reformation Protestant sects which rejected established 
church and secular state authority in their communist or communitarian interpretations of the Bible. The Anabaptist rebellions of the 1520s, the revolts of the Diggers and Levellers during the English Revolution, and the establishment of the early Puritan colonies in the "new promised land' of New England during the $17^{\text {th }}$ century, were inspired by post-millennialist apocalyticism. It is notable that Luther, who drew heavily on biblical apocalyptic narratives to attack the Church of Rome during the Reformation, questioned the canonicity of the book of Revelation because of its ambiguity and lack of theological rigour. In Luther's eyes, these weaknesses led to its appropriation by 'fanatical' utopian rebels like the Anabaptists led by Thomas Muntzer, but also to its abuse in the hands of the Roman Church who exploited it in the service their own worldly power (Mjaaland 2013). In the post-revolutionary United States, post-millennialism was especially influential as it co-mingled with Enlightenment thought to inform progressive democratic and social reform in the building of the ideal 'City on the Hill', and inspire pre-figurative community experiments in utopian living.

During the $20^{\text {th }}$ century, evangelical fundamentalisms allied to premillennialist eschatology became the dominant force in American Protestant Christianity, and was exported across the globe by missionaries. Premillennialism is premised on the view that an apocalyptic final judgment will take place before the millennial rule of the saints. It is the duty of Christians to prepare by remaining spiritually active and spreading God's word - indeed success of the latter might even hasten Christ's return. However, all attempts to significantly improve social relations through progressive reform are ultimately futile because human beings are infected by original sin, and require Christ's grace for their redemption. Dovetailing with conservatism's critique of liberalism as being built on a flawed conception of human nature, Pre-Millennialist evangelicals consider notions of socially engineered perfectibility as humanist and therefore un-Christian. Hence, corrupt human civilisation stands condemned with no exit except via the immanent apocalypse where Christians will make the transition to utopia. In the contemporary period, the three apocalyptic traditions - amillennialism, postmillennialism and pre-millennialism - remain locked in a theological conflict for the soul of Christianity.

\section{Apocalypse Myth, Utopian Ideology and Modernity}

Apocalypticism is a recurrent mythic narrative that has been employed by successive generations to create symbolic meanings about their experience of the world and their place in it. By heightening a consciousness of historical time, past and future are brought together in an 
intensified sense of the present which spurs different types of social, religious or political action depending upon the contents of the apocalyptic revelation. Myths have a symbiotic relationship with ideologies. Myths dwell upon ontological questions of being and time, life and death, places and origins. Ideologies operate more systematically, pragmatically, and at a greater level of generality to address the question of power in society (Eagleton 1991). In doing so, ideologies often utilise mythic narratives to explain, challenge or legitimise power, while myths operate as a form of ideology in narrative form (Lincoln 2002).

Social movement organisations often employ mythic narratives as forms of rhetoric and propaganda that are used to frame issues in a manner resonant with target publics, and thereby facilitate mobilisation. However, as Levitas (1990, p. 82), shows, 'mobilising myths' are not unproblematic in that their appeals to passion can potentially be fused with any political ideology of left or right. Georges Sorel, for example, in his syndicalist phase, wrote his most important work Reflections on Violence (2008, [1908]), as a theorisation of the apocalyptic 'myth of the general strike'. According to Sorel, this myth generates a heroic 'entirely epic state of mind' amongst the working class, and is the source of the vitalistic energy that will hasten the overthrow of bourgeois society and facilitate moral renewal. Despite claiming to be writing in 'the spirit of Marx', only a few years later Sorel was to flirt with extreme nationalism and anti-Semitism, and after the First World War was to express admiration for both Mussolini's fascism and Lenin's Bolshevism. These political vacillations are arguably related to Sorel's attempt to use myth to combat the abstract rationality of parliamentary politics, and the dogma of 'official' $2^{\text {nd }}$ International socialism.

In developing a sociology of knowledge around the distinction between ideology and utopia, Mannheim (1960), uses the latter concept in a way that resembles Sorel's use of myth (Levitas 1990). Ideology is defined in a critical Marxist manner as incongruous with reality, and used to legitimise the social and political status quo through mystification. Utopia is equally incongruous with reality, but embodies 'situationally transcendent ideas' which may have a transforming effect upon the existing historical-social order (Mannheim 1960, p. 185). Like the relationship between myth and ideology, the relationship between utopia and ideology is not a simple binary; rather, there is constant dialectical interpenetration. Although wary of the dangers of irrationalism generated by the 'ecstatic chiliasm' that animates all utopianism, Mannheim argues that it remains a vital component of all progressive social and political thought. Reflecting Lukacs' critique of reification, Mannheim argues (1960, p, 236) that 
without utopia 'man himself becomes no more than a thing' due to the corrosive effect upon the human will of ideology which has become all encompassing.

In his sweeping account of the relationship between the apocalypse and the making of modernity, Hall (2009a) designates Judaism, Christianity and Islam as the 'apocalyptic axis', where notions of collective religious and ethnic identity become concomitant with notions of manifest destiny. Different religious-political currents took divergent approaches 'from quietistic fatalism and conformity, through hope and faith, to militancy, holy war and escape to the "other side" - paradise, either a utopian "heaven on earth" or through martyrdom or collective suicide, the realm beyond life' (Hall 2009a, p. 41 and 42). In Hall's account, the mid$9^{\text {th }}$ century marks 'the end of the beginning of modernity' because two crucial pre-requisites of the modern temporal sensibility - historical telos related to a people's fate, and the apocalypse as a crucial turning point leading to destruction or renewal - had, through conquest and conversion, become widely disseminated in Europe, North Africa and central Asia.

As modernity develops, the apocalypse narrative is increasingly contested as it is formed and reformed in the service of heretical religious sects and oppositional social and political movements, where it is associated with revolution and utopia (Cohn 2004, Hobsbawm 1965, Thompson 1991). At the same time, repeated attempts are made by church and state to appropriate and make safe a discourse that is potentially dangerous to religious, political and social order. While the apocalyptic was central to the conflictual processes that brought mature modernity (e.g. the Reformation, and the bourgeois revolutions), for the new ruling classes there is no place for a critical utopian narrative that is so at odds with official discourses of liberal progress, and is disruptive of the rational objective temporality that is required in the world of capital and wage labour. Contained, remoulded, or excluded by official ideologies and theologies, the apocalyptic narrative myth nevertheless continually regenerates and reinvents itself like a polysemic hydra (Hall 2009a). The debate inside and outside today's green movement surrounding the political implications of global warming is the latest manifestation of this age-old contest between the dream of a radical break with the present social order and the powerful interests who seek to preserve that order.

\section{Apocalypticism and the Spirit of Modern Environmentalism}

In the $21^{\text {st }}$ century, it would appear that, instead of being a suppressed pariah discourse, apocalypticism has become so ubiquitous as to be almost banal. Contemporary society is 
wracked by an unending sense of crisis - economic, political, social, medical, moral and environmental - which is circulated via global media, and reinforced by cultural products that speculate endlessly about the end of the world. Moreover, fundamentalist strains of religion with developed apocalyptic narratives, and populist political movements that employ apocalyptic rhetoric, have gained significant ground across the globe. Sociologists of the antienvironmentalist right such as Furedi (2002) describe a paralysing culture of fear that holds back development and progress, while those of the ecological left such as Beck (1994) detail a world risk society increasingly driven by reflexive responses to the apocalyptic side-effects of first order modernisation.

The apocalypticism that suffuses contemporary culture is different from that of the past because it has been largely separated from its original 'secret utopian vocation' (Jameson 2007, p. 199). The horrors of $20^{\text {th }}$ century history, from the two World Wars, the gulags and the Holocaust, through nuclear warfare and the failure of communism, coupled with seemingly intractable crises, mean that dystopia has replaced utopia as the dominant mode of speculative cultural imagination. At a philosophical level, the postmodern discourse of 'incredulity towards metanarratives' (Lyotard 1984) and, at a political level, the influential critiques of conservative writers who equate apocalyptic discourse with terror (e.g. Cohn 2004) and designate utopianism as inherently totalitarian (e.g. Popper 2002), are often used by critics to undermine any social movement project that advocates radical social change. As Kumar (1993) says pointedly of the hollow apocalypse experienced by Fukuyama's (1992) last man:

'The end of history brings nothing new. Quite the opposite. It announces the final victory of the old. What was thought to be new has failed. It was in any case, a bundle of delusions, unnecessary and destructive deviations... We already live in the millennial new age, the last age' (Kumar 1993, p. 62).

In response to this melancholic resignation, Kumar (1993, p.80), argues that the present juncture contains resources of hope that stem from an 'unprecedented historical condition'. State communism is over, and although liberal consumer capitalism is hegemonic, there is a growing realisation that it has led to a situation in which life itself is threatened with insupportable damage, perhaps even extinction'. The failure of modernist ideologies creates possibilities for a break with the past, and the diagnosis of environmental apocalypse, a necessity for 'the invention of something new, a rebirth that is also a renewal of History'. 
Modern environmentalism has had an intimate relationship with apocalyptic narratives since its inception. In the 1950s, eco-dystopias like Wyndham's The Day of the Triffids (1951), and Christopher's Death of Grass (1956), were cultural precursors to Carson's Silent Spring (1962), which is usually credited as the foundational text of the modern green canon. In the first chapter, "A Fable for Tomorrow," Carson paints a bleak future world where "everywhere was a shadow of death... there was a strange stillness'. She rhetorically asks 'the birds for example -where had they gone?', before coming to her apocalyptic punchline that 'it was a spring without voices' (Carson 2000: 22). Carson goes on to set out a detailed scientific critique of the negative effects of pesticide use, before concluding with a plea that echoes Bunyan's Christian fable Pilgrims Progress (1678), to take the 'less travelled road', and thereby ensure the preservation of life on Earth.

Later key environmental movement texts shift the focus to other areas of concern but are no less apocalyptic in tone. For example, Ehrlich's best-selling Population Bomb (1971), and Hardin's influential "Tragedy of the Commons" (1968) thesis, made apocalyptic predictions about the effects of overpopulation. The Club of Rome's Report The Limits to Growth (1972) provoked fierce debate about its apocalyptic predictions concerning resource depletion, and inspired further publications like The Ecologist's A Blueprint for Survival (1974). In the same period, the first iterations of Lovelock's Gaia Hypothesis were produced (see e.g. The Quest for Gaia, 1975), which argues scientifically that the Earth's eco-system self-regulates to provide the conditions for life, but that human activity is increasingly putting this capacity in jeopardy with potentially catastrophic consequences. In the 1980s, the Brundtland Report, Our Common Future (1987), called for sustainable development in the face of time running out to deal with a plethora of local threats (desertification, deforestation, toxic wastes, acidification), and global risks (climate change, ozone depletion and species loss), which together threaten the future.

By the late 1980s, a paradigm shift in climate science had taken place whereby it became generally accepted in the scientific community that anthropogenic climate change was underway, and that it poses the single most important apocalyptic threat to Earth's life sustaining eco-systems (Weart 2011). Formed in 1988, the IPCC produced its First Assessment Report in 1990, which formed a cornerstone of the 1992 Earth Summit discussions in Rio. The four subsequent IPCC Reports are progressively more strident in their exhortations to curtail climate change, and in their warnings about the consequences if this does not happen. This is 
despite the conservatism inherent to consensus formation in large bureaucratised communities, and political pressures to present scientific data in neutral language to ensure that the situation appears manageable to world publics. Indeed, there is strong evidence of 'systematic understatement of climate risk' throughout the short history of the IPCC (Wynne 2010).

Whether the issue is pesticide use, population growth, resource depletion, genetic modification, nuclear power or greenhouse gas emissions, modern environmentalism has been animated by the revelations of science which have informed apocalyptic warnings to take a precautionary approach to techno-scientific risk. This marks a profound difference with previous incarnations of the apocalypse which were divinely inspired, and with versions advanced by the antecedents of modern environmentalism which centred on romantic-ethical rejections of industrial capitalist society. But as the history of modern social movements indicates, science is not enough on its own to mobilise individuals to participate in social movement activities. As Lowith (1949, p.45) pointedly says of Marx's apocalyptic vision 'It would have been quite impossible to elaborate the vision of the proletariat's messianic vocation on a purely scientific basis and to inspire millions of followers by a basic statement of facts'. Rather, as Marx recognised, science must be aligned with ethical and political concerns which bring social meaning to the scientific data that has been generated. In other words, a compelling narrative which points to attractive future possibilities, as for example articulated in the Communist Manifesto (1848), and popularised through all available channels, is required to inspire a generation to take radical collective action.

\section{Apocalyptic Affinities: Christian Theology and Green Ideology}

The unfolding environmental apocalypse clearly adds special urgency to Lenin's question: 'what is to be done?'. Contemporary green politics answers it from two key perspectives which have very different relationships to power. On the one hand, there is a strategic mainstream wing that operates primarily in and through states, markets and parliamentary systems: green politics from above. On the other, there is a radical pre-figurative wing, which operates in and through activist networks, social movement organisations and extra-parliamentary activity: green politics from below. Most green actors operate in the space between these ideal-typical poles of the continuum (Anderson 2010).

Foster (2009), summarises current mainstream green approaches as operating through three interrelated strategies. First, the use of 'technological bullets', a strategy related to the 
prominence of science in the apocalyptic diagnosis, and connected to the other key resource of utopian (and dystopian) thought in the $21^{\text {st }}$ century: digital technologies and human-machine interfaces. Here, scientific solutions are required for what are primarily defined as scientific problems. Bruckner (2013, p. 185) for example, argues that industrial society contains the answer to the ecological crisis and that "we have to count on the genius of the human race to overcome its fears and improvise new solutions'. Second, the extension of the market to all aspects of nature, so that a future green or even 'natural' capitalism is envisaged. Hence, 'the climate can be protected for fun and for profit' (Hawken et al 1999: 256). Third, market demand 'creating islands of preservation in a world of almost universal exploitation and destruction of natural habitats' (Foster 2009, p. 274). Ecological modernisation perspectives view the environmental movement and market mechanisms as working hand in hand to create new forms of global green governance and economy (Spaargaren et al 2000, Mol 2003).

In terms of Christian theology, mainstream environmentalism has a distinct affinity with amillennialism. Like amillennialism, mainstream environmentalism does not challenge the underlying structures of 'this world' in the form of the state and market systems. The environmental apocalypse might be a mobilising myth but it is an 'apocalypse light' myth which is used to promote modernisation of the capitalist economy. There may be rituals that should be practiced, such as recycling, energy efficiency, conservation and especially ecofriendly consumerism, but overall a kind of green nominalism is favoured. The future should be trusted to the expertocracy of climate scientists, departments of the environment, green entrepreneurs, state-corporate-NGO partnerships and international carbon brokers. Publics shouldn't panic or react too strongly to climate science revelations; instead it is business as usual with a green tinge in this most manageable and depoliticised apocalypse.

Radical environmentalism includes a myriad of competing organisations, tendencies and factions variously influenced by green socialist, communitarian, feminist and anarchist ideas, as well as an eclectic mixture of ecosophies and world religions. These diverse strands inevitably stir up disagreement and debate, but most radical green activists agree on a loosely defined political agenda: critical engagement with the short-term prioritisation of economic growth that has deformed modern society and brought the Earth's eco-system into apocalyptic crisis; and reconstruction of the human relationship with nature on a long-term sustainable basis that necessarily respects the inter-connectedness of all life. Radical greens share a refusal 
of 'this world' at the level of the self, lifestyle, organisational practice and wider political strategy. Smith (2001, p. 132) indicates affinity to Christian non-conformity when he explains:

Radical environmentalism has many parallels with past antinomian protests, in rejecting the supposed ethical authority of those social institutions and theoretical frameworks that attempt to define norms and beliefs of behaviour. Radical ecology 'places moral commitment above positive law' and is characterised by a 'hermeneutics of suspicion' directed toward the establishment in all its forms and extending to all attempts to 'lay down the law'.

While much is shared between the diverse stands of radical environmentalism, there are also significant differences. The conflicting philosophies of the two paradigm-defining tendencies, social ecology and deep ecology (Bookchin 1995, Dregson et al 2010), are brought into high relief if comparisons with post and pre-millennial Christian apocalyptics are made.

Social ecology has an affinity with post-millennialism in the way it prioritises social and ethical concerns. There is a belief that human-society-nature relationships can be progressively transformed through collective political activity that challenges the social order, and prefigures the type of ecotopian community necessitated by the current ecological crisis. The apocalypse is a revelation about the inherently destructive nature of the capitalist economy that can be used to inform an ecological revolution which links social and environmental justice to sustainability. For social ecology, apocalypticism is therefore a critical method that offers a way out for humanity. In contrast, deep ecology prioritises the spiritual dimension because, like premillennialism, it views human civilisation as inherently corrupt and therefore unamenable to meaningful progressive change. Indeed, human civilisation per se is held culpable for the unfolding environmental apocalypse.

If society cannot be changed, focus shifts to pre-figurative transformation of the self. For spiritual deep ecologists consciousness-raising through meditation, spiritual rituals, alternative therapies, and symbolic representations of Mother Earth, all become important re-sacralising facets of ecological practice (Taylor 2009). Deep ecological veneration of wilderness experience has close parallels with traditions of Christian asceticism (Adler 2006), while the notion of 'green fire' inspiring and spreading the message is analogous to the Christian conception of the Holy Spirit (Taylor 1991). The notion of God/Nature being within human beings, and human beings as therefore part of God/Nature, was central to the antinomian 
tendencies of some radical Christian sects of the past (e.g., the Ranters of the $17^{\text {th }}$ century (Cohn 2004)). It is also important to the beliefs of some of today's deep greens who have developed a theological ontology that is informed by a fatalistic apocalypticism. In some deep ecological writing, there is even a sense that the prospect of an environmental apocalypse is to be welcomed as an unpleasant but necessary cleansing path to ecotopia (see some of the anarchoprimitivist contributions to the Against Civilisation collection (Zerzan 2005).

\section{Apocalyptic Revelation as Hope and Despair}

McIntosh frames the global warming apocalypse as containing utopian potentials because it has decisively 'lifted the veil' that hides the dark side-effects of industrial civilisation. As McIntosh (2010, p.10) argues, 'we might do all we can to mitigate the causes of global warming' but the 'signs of the times' reveal 'an incredible opportunity to evolve culturally in what it means to be human beings, growing in decency and dignity to help one another and other species adapt better to come-what may in the come-to-pass'. In McIntosh's (2008) wider work on global warming, the framing of the environmental apocalypse as a revelation and an opportunity is linked to advocacy of a twelve-point programme of 'cultural psychotherapy', centred on a rejection of consumer society in favour of human and planetary welfare, and embrace of syncretic ecological spiritualties.

Klein (2014), frames global warming in a similar millenarian manner (though without the spiritual baggage) in her best-selling book This Changes Everything. For Klein, the apocalyptic revelation that neo-liberal capitalism has brought the world to the edge of ecological collapse has the potential to radically change public consciousness and mobilise powerful global social movements to demand transition to a low-carbon socially just society. She argues that the fastgrowing global movement for climate justice, which campaigns for carbon divestment, and demands that carbon-related resources be left undisturbed, can be compared to the $19^{\text {th }}$ century movement for the abolition of slavery which successfully forced entrenched social and economic interests to write off trillions of dollars of wealth (Klein 2014, p. 456).

Such millenarian optimism stands in sharp contrast to the way that John's Revelation and related biblical passages have usually been represented in the popular apocalyptic imagination. Revelation has fuelled a sublimated nightmare 'other' percolated through the imagery of artists 
like Bosch and Breughel, that accompanies official discourses of progress and civilisation. All notions of utopian renewal are forgotten as the 'four horsemen of the apocalypse' (conquest, war, famine and death) are unleashed as wrathful harbingers of God's final judgement. There is a strand of contemporary green thinking that frames global warming in line with this despairing perspective. For dystopian greens, the ecological apocalypse that is unfolding may not be about the end of all life on earth, but it is about the end of the modern way of life, with all the consequences that such an ending will entail.

Lovelock (2007, p. 1), for example, states that 'we are so abusing the Earth that it may move back to the hot state it was in fifty-five million years ago, and if it does, most of us, and our descendants will die. It is as if we were committed to live through the mythical tale of Wagner's Der Ring des Nibelungen and see our Valhalla melt in torrid heat'. The 'revelation' of global warming heralds an almost certain civilisation-shattering catastrophe that will force the small band of humans who survive to endure Hobbesian lives in a "chaotic world ruled by brutal warlords on a devastated earth' (Lovelock 2007, p. 198). The UK-based Dark Mountain Project brings together a collection of 'artists, writers, craftspeople and workers with practical skills' to reflect 'an age of material decline, ecological collapse and social and political uncertainty', but explicitly states in its Manifesto that any attempt to halt the process would be futile. Indeed, climate change 'brings home at last our ultimate powerlessness' in the face of the apocalyptic revenge of nature (Kingsnorth and Hine 2009). The utopic millenarianism of McIntosh and Klein, and the dystopic apocalypticism of Lovelock and the Dark Mountain Project, represent two ideal-typical polarities in the ways the environmental apocalypse is currently being framed in green political thought.

\section{Conclusion: Which Apocalypse? Whose Utopia?}

If 'the apocalypse is the mother of all Christian theology' (McGinn, 1995, p. 61), it is clear from the exposition I have presented that it is also one of the parents of contemporary environmental politics; the other is modern science. These parents have a tempestuous but productive relationship that pivots around the dynamic tensions created by bringing a powerful narrative myth together with a rational analytical framework that generates falsifiable results about the effects of human actions upon the natural world. Comparative analysis shows that, like the history of Christianity as a religious social movement in its initial insurgent and later militant Reformation and post-Reformation phases, modern environmentalism was born, shaped and animated in the post-World War Two period by the spirit of apocalypticism. 
Exploration of the two competing traditions of apocalyptic Christian theology, postmillennialism and pre-millennialism, reveals affinities with utopian millenarianism in the key currents of radical green thought and political practice: social ecology and deep ecology. Similarly, when Christianity was established, institutionalised and codified by church leaders working with the Roman power elite, as in mainstream market-driven forms of contemporary environmentalism, the most immediate elements of its apocalyptic ideological perspective were suppressed, softened or refashioned into an official discourse of amillennialism which serves the interests of entrenched social and economic power. The contemporary debate about apocalypticism and global warming is therefore an important and deeply political controversy about the relationship of environmentalism to institutions and power.

What matters above all for green politics in the $21^{\text {st }}$ century is the type of apocalypticism that becomes dominant - will it be one that emphasises endings or new beginnings? The status of the apocalypse in western culture tends towards cataclysmic ending and civilizational disaster that translates environmentally into what Kingsnorth (in Monbiot 2009) calls McCarthyism (after the desolate vision of ecological dystopia described in Cormac McCarthy's seminal novel The Road (2007)). Millenarian environmentalists such as McIntosh, critical intellectuals such as Klein, and greens associated with various branches of social ecology attempt to rescue the unfolding environmental apocalypse from this debilitating negativity and reconnect it to its original utopian promise. In this broadly social ecological discourse, the apocalypse is deployed critically as a revelation about both the rapacious unsustainable nature of capitalist modernity, and the positive utopian potentials existing within the here and now for the type of social-ecological revolution that global warming necessitates. Its task is however made difficult by dystopian greens such as Lovelock and some strands of deep ecology, whose fatalistic apocalypticism is steeped in pessimism about human civilisation.

In political terms, the biggest obstacle to social ecological reconstruction is the way in which the apocalyptic revelation of global warming has been harnessed by state and market interests to signify the necessity for ecological modernisation. Mainstream forms of environmentalism have propagated the notion of a relatively seamless transition to a technologically advanced low carbon economy without a concomitant change to social relations. As Jameson observes, neo-liberal ideology is so pervasive that it is easier to imagine the end of the world than the end of capitalism (Jameson 2007, p. 199). The ongoing failure to meet almost every international carbon reduction target, and the likelihood that the 2015 United Nations Paris 
Agreement will fail to hold global temperatures to the agreed 1.5 degrees Celsius above preindustrial levels, indicate that the greening of contemporary capitalism is hopelessly utopian in the Marxist pejorative sense. It seems that in developing and circulating a fantasy mythic narrative about a greened free market economy, world elites would in fact rather see the end of the world than the end of neo-liberal capitalism.

The history of social movements shows that entrenched social and economic power can be challenged, but only when facts about past and present are allied with visions of alternative futures that capture the public imagination. In the current historical juncture, it is the task of green movement activists and organisations to carefully draw upon contested politicalideological discourses and cultural resources - including utopian narratives - to generate and publicize resonant frames that connect people to current events, generate critical thought and inspire change. Classic utopian novels by writers as diverse as William Morris (News from Nowhere 2009), Ernest Callenbach (Ecotopia 1990), Ursula Le Guin (The Dispossessed 1999) and Marge Piercy (Woman on the Edge of Time) engage in the type of creative 'transgressive fooling' (Sargisson 2012) that is vital at the level of imagination for the green project. They are joined by writers in the broad social ecology tradition in political philosophy which seeks environmental justice (Shrader-Frachette 2002), and by popular commentators such as Mason (2015), who articulate ecologically sensitive post-capitalist futures. In terms of concrete application, there are a myriad of green utopian social and environmental projects in community, energy, waste, transport and city planning. These projects share a refusal of the current social and economic system and engage in active utopianism to try to bring about change (for examples, see Bradley and Hedren, 2014). Together, these types of utopian vision and active practice facilitate the type of radical thinking that challenges common-sense perceptions of what is possible in terms of future social and economic development as well as critiquing the present. They constitute vital resources of green hope in the face of the elite mantra that there is no alternative to the current socio-economic system and the environmental crisis that it perpetuates.

Here, I have shown that throughout its short history modern environmentalism has used apocalyptic narratives to diagnose the ecological crisis, puncture official discourses of liberal progress, and suggest alternative utopic visions of the future. I have also argued that attempts by market-driven green politics from above to colonise and pacify apocalyptic discourse resemble those of the established Church to assert its power and curb the insurgency of 
Christianity from below. The Christian apocalyptic tradition shows that if the green movement is to retain its radical edge in the $21^{\text {st }}$ century it must resist this official appropriation of the apocalypse, and make its 'secret utopian vocation' public to build a politics of millennial hope.

\section{References}

Adler, J., 2006. Cultivating Wilderness: Environmentalism and Legacies of Early Christian Asceticism. Comparative Studies in Society and History: an International Quarterly. Cambridge University Press, Vol 48, 4-37.

Anderson. J., 2010. From 'Zombies' to 'Coyotes': Environmentalism Where We Are. Environmental Politics. 19: 6, 973-991.

Angus, I., 2013. The Myth of 'Environmental Catastrophism’. Monthly Review, 65 (4), $15-28$.

Barkun, M., 1986. Disaster and the Millennium. Syracuse: Syracuse University Press.

Beck, U., 1994. Risk Society. London: Sage.

Benson, J., ed., 2000. Environmental Ethics. London: Routledge.

Bookchin, M., 1995. Re-enchanting Humanity, A Defense of the Human Spirit Against Antihumanism, Misanthropy, Mysticism and Primitivism. London: Continuum.

Bradley, K. and Hedren, J., eds. 2014. Green Utopianism. London: Routledge.

Bruckner, P., 2013. The Fanaticism of the Apocalypse. Oxford: Polity.

Brundtland, G. H., 1987. Our Common Future. Oxford: Oxford University Press.

Buell, F., 2004. From Apocalypse to Way of Life. Environmental Crisis in the American Century. London \& New York; Routledge.

Bull, M., ed., 1995. Apocalypse Theory and the Ends of the World. Oxford: Blackwell. Bunyan, J., 2003. Pilgrim's Progress. Oxford: Oxford University Press.

Callenbach, E., 1990. Ecotopia. New York: Bantam.

Carson, R., 2000. Silent Spring. London: Penguin.

Christopher, J., 2009 The Death of Grass. London: Penguin.

Cochrane, C. N., 2003. Christianity and Classical Culture. Indianapolis: Liberty Fund Inc.

Cohn, N., 1995. How Time Acquired a Consummation. In: Bull, M. ed., Apocalypse Theory and the Ends of the World. Oxford: Blackwell, 21-37.

Cohn, N., 2004. The Pursuit of the Millennium. London: Picador. 
Dobson, A., 1997. Green Political Thought. London \& New York: Routledge.

Dregson, A., Devall, B., and Naess. A., eds., 2010. The Ecology of Wisdom: Writings by Arne Naess. Berkeley: Counterpoint.

Eagleton, T., 1991. Ideology. London: Verso.

Ehrlich, P., 1971.The Population Bomb. Cutchogue, N.Y. : Buccaneer.

Feinberg, M. and Willer, R., 2011. Apocalypse Soon? Dire Messages Reduce Belief in Global Warming by Contradicting Just World Beliefs. Psychological Science, 22(1), 34-38.

Foster, J. B., 2009. The Ecological Revolution: Making Peace with the Planet. New York: Monthly Review Press.

Foust, C. R. and Murphy, W. O’S., 2009. Revealing and Reframing Apocalyptic Tragedy in Global Warming Discourse. Environmental Communication, Vol 3, (2), 151-167.

Fukuyama, F., 1992. The End of History and the Last Man. New York: The Free Press.

Furedi, F., 2002. Culture of Fear. London: Continuum.

Giddens, A., 2015. The Politics of Climate Change. Oxford: Polity.

Ginn, F., 2015. When Horses Won't Eat: Apocalypse and the Anthropocene. Annals of the Association of American Geographers, 105 (2), 351-359.

Goldsmith, E. ed., 1974. A Blueprint for Survival. London: Signet.

Guin-Le, U., 1999. The Dispossessed. London: Gollancz.

Hall, J. R., 2009a. Apocalypse: From Antiquity to Empire of Modernity. Cambridge: Polity.

Hall, J. R., 2009b. Apocalypse in the Long Run: Reflections on Huge Comparisons in the History of Modernity. Sociological Research Online, 14(5)10.

Available from:

https://www.researchgate.net/publication/46559282_Apocalypse_in_the_Long_Run_

Reflections_on_Huge_Comparisons_in_the_Study_of_Modernity

[Accessed April 2016].

Hall, J, R., Schuyler, P. D. and Trinh, S., 2000. Apocalypse Observed. Religious Movements and Violence in North America, Europe and Japan. London, New York: Routledge.

Hardin, G., 2000. The Tragedy of the Commons. In: J. Benson (ed.), Environmental Ethics. London: Routledge, pp.185-196. 
Hobsbawm, E., 1965. Primitive Rebels. London: Norton.

Hoggert, P., 2011. Climate Change and the Apocalyptic Imagination.

Psychoanalysis, Culture and Society, 16, (3), 261-275.

IPCC (2014) Climate Change 2014: Synthesis Report. Contribution of Working

Groups 1, 2 and 3 to the Fifth Assessment Report of the Intergovernmental Panel on

Climate Change [Core Working Team, R. K. Pachauri and L.A. Meyer (eds)],

Geneva, Switzerland: IPCC.

Jameson, F., 2007. Archaeologies of the Future. London: Verso.

Kingsnorth, P. and Hine, D., 2009. Uncivilisation: The Dark Mountain Manifesto.

http://dark-mountain.net/about/manifesto/ [Accessed May 2016].

King James Bible, 1611. http://www.kingjamesbibleonline.org/2-Peter-Chapter-3/

[Accessed 29/02/16].

Kumar, K., 1993. The End of Socialism? The End of Utopia? The End of History? In;

Kumar, K. and Bann, S., eds. Utopias and the Millennium. London: Reaktion, 63-80.

Kumar, K. and Bann, S., eds. 1993. Utopias and the Millennium. London: Reaktion.

Leiserowitz, A., 2005. American Risk Perceptions; Is Climate Change Dangerous?

Risk Analysis 25 (6), 1433-42.

Levitas, R., 1990. The Concept of Utopia. Hemel Hempstead: Phillip Allan.

Lincoln, B., 2002. Theorizing Myth: Narrative, Ideology and Scholarship. Chicago and London: University of Chicago Press.

Lovelock, J., 2007. The Revenge of Gaia. London: Penguin.

Lovelock, J. and Epton, S., 1975. The Quest for Gaia. New Scientist, 65 (935), 304306.

Lowith, K., 1949. Meaning in History. Chicago: University of Chicago Press.

Lyotard, J. F., 1984. The Postmodern Condition: A Report on Knowledge.

Manchester: Manchester University Press.

Mason, P., 2015. Post-Capitalism: A Guide to Our Future. Milton Keynes: Allen Lane.

Marx, K. and Engels, F. 1990. Manifesto of the Communist Party. Beijing: Foreign Languages Press.

McCarthy, C., 2007. The Road. London: Picador.

McGinn, B., 1995. The End of the World and the Beginning of Christendom. In: Bull, M. ed, Apocalypse Theory and the Ends of the World. Oxford: Blackwell, 58-89.

McKinley, A., 2008 Hope in a Hopeless Age: Environmentalism's Crisis.

Environmentalist 28, 319-326. 
McIntosh, A., 2010. Forward. In: Skrimshire, S. ed. Future Ethics: Climate Change and the Apocalyptic Imagination. London: Continuum, vii-xi.

McIntosh, A., 2008. Hell and High Water: Climate Change, Hope and the Human Condition. Edinburgh: Birlinn.

Meadows, D. H., et al., 1974. The Limits to Growth: a Report for the Club of Rome's Project on the Predicament of Mankind. New York: Universe Books.

Mjaaland, M. T., 2013. Apocalypse and the Spirit of Revolution, Political Theology, 14(2), 155-173.

Mol, A. P. J., 2003. Globalization and Environmental Reform. Cambridge, MA: MIT Press.

Monbiot, G., 2009. Should we seek to save industrial civilisation? A debate with Paul Kingsnorth. The Guardian: 18/08/09.

Morris, A, D. and Mueller, C. M., eds., 1992. Frontiers in Social Movement Theory. New Haven, CT: Yale University Press.

Morris, W., 2009. News from Nowhere. Oxford: Oxford University Press.

Nordhaus, T., 2013. The Climate Casino: Risk, Uncertainty, and Economics for a Warming World. New Haven and London: Yale University Press.

Northcott, M., 2004. An Angel Directs the Storm. Apocalyptic Religion and American Empire. London, New York: I.B. Tauris.

Pascal, B., 1995. Pensees. Tr. A.J. Krailsheimer. London: Penguin.

Piercy, M. 2016. Woman on the Edge of Time. London: Del Rey.

Popper, K., 2002. The Open Society and its Enemies. London \& New York: Routledge.

Sargisson, L., 2012. Fool's Gold? Utopianism in the $21^{\text {st }}$ Century. London: Palgrave.

Schrader-Frachette, K., 2002 Environmental Justice: Creating Equality, Reclaiming Democracy. Oxford: Oxford University Press.

Shellenberger, M. and Nordhaus, T., 2004. The Death of Environmentalism: Global Warming Politics in a Post-Environmental World. New York: The Breakthrough Institute.

Skrimshire, S. ed., 2010. Future Ethics: Climate Change and the Apocalyptic Imagination. London: Continuum.

Smith, M., 2001. An Ethics of Place: Radical Ecology, Postmodernity and Social Theory. New York: SUNY Press.

Snow, D, A. and Benford, R, D., 1992. Master Frames and Cycles of Protest. In: Morris, A, D 
\& Mueller, C. M eds., Frontiers in Social Movement Theory. New Haven, CT: Yale University Press, 133-155.

Sorel, G., 2008. Reflections on Violence. Cambridge: Cambridge University Press. Spaargaren, G., Mol, A. P. J., and Buttel, F. H., eds. 2000. Environment and Global Modernity. London: Sage.

Stern, N., 2007. The Economics of Climate Change: The Stern Review Cambridge: Cambridge University Press.

Swyngedouw, E., 2010. Apocalypse Forever? Post-political Populism and the Spectre of Climate Change. Theory, Culture and Society, 27(2-3) 213232.

Taylor, B., 1991. The Religion and Politics of Earth First! The Ecologist 21(6), 258-266.

Taylor, B., 2010. Dark Green Religion: Nature Spirituality and the Planetary Future. Berkeley/ Los Angeles/London: University of California Press.

Thompson, A., 2009. Responsibility for the End of Nature; Or, How I Learned to Stop Worrying and Love Global Warming. Ethics and the Environment, 14 (1), 77-99.

Thompson, E. P., 1991. The Making of the English Working Class. London: Penguin.

Urry, J., 2011. Climate Change and Society. Cambridge: Polity.

Veldman, R. G., 2012. Narrating the Environmental Apocalypse. Ethics and the Environment, 17(1), 1-23.

Weber, E., 1999. Apocalypses. London: Random House.

Weart, S., 2011. How Skepticism Became Denial. Bulletin of the Atomic Scientists, 67 (1), 41-50.

Wojcik, D., 1997. The End of the World as We Know it: Faith, Fatalism and Apocalypse in America. New York; New York University Press.

Wyndham, J., 2008. The Day of the Triffids. London: Penguin.

Wynne, B., 2010. Strange Weather, Again: Climate Science as Political Art. Theory, Culture and Society, 27 (2-3), 289-305.

Zerzan, J. ed., 2005. Against Civilisation: Readings and Reflections. Los Angeles: Feral House. 
